\title{
The Plantation Economy Model and the Caribbean
}

\section{Dennis Pantin}

This article attempts a critical appraisal of the plantation economy model (PEM), concentrating on the work of Best and Levitt | 1968. 1975| and, to a lesser extent, of Beckford [1972, 1974]. Reference will be made also to other published work of Best relevant to the discussion of the formal model $[1965,1968,1971$. 1971a. 1978|. Several empirical studies carried out by Caribbean economists within a similar framework /eg Girvan 1971, Jefferson 1972, Thomas 1974| will not be considered here. since they all share similar ground with the PEM. Although Thomas work is written within an avowedly marxist paradigm. his historical analysis is very close to the PEM.

\section{The Plantation Economy Model}

The PEM can be placed in the general structuralist/ historical/institutional methodological tradition. Best and Levitt argue that the present-day structure of Caribbean economies can only be understood by invoking the resources of history" |Best and Levitt 1968|. Following Seers [1963] and Myrdal| 1957|. they call for the outline of a typology of economic systems and seek to detail the mechanism of one such type - the plantation economy.

If the PEM is to be placed within the trifocal division of dependency thought suggested by O'Brien [1975]. its emphasis on the analysis of specific situations suggests membership of the group which includes Cardoso. However, the methodology of the analysis itself shares some similarity with the work of Sunkel [1973] and Furtado [1970|.

The international context of dependency is considered by the PEM insofar as plantation economies are placed within the general class of export-propelled economies and as one subset of the hinterlands created by colonial expansion. Three types of hinterlands are identified: those of conquest. settlement and exploitation. Hinterland economy is distinguished from metropolitan economy to which it bears a symbiotic relationship: the locus of discretion and choice rests in metropolitan economy. The relationship between the two may be summarily described as mercantilist | Best and Levitt 1968:14]. Hinterlands of conquest are meant to correspond to the case of Spain in Andean America and New Spain. Here metropolitan interest is seen to be not so much in land as a productive asset, but in the organisation of people to facilitate the redistribution and transfer of wealth. Hinterlands of settlement correspond to the north and middle colonies of North America where mercantilism expresses itself less in the direct organisation of production and more in detailed regulations concerning what may be produced and the terms and manner in which trade may proceed. In hinterlands of exploitation, of which the plantation economy is part, metropolitan interests shift from plunder and exchange towards production for trade.

It can easily be discerned that the international generalisation suggested by the hinterland-metropole analysis corresponds largely to New World societies and to some Pacific cases such as Australia or Mauritius. It is of little relevance to the case of most of Africa and Asia where imperialist penetration was not total. Moreover, in the case of North and South America one can identify overlapping hinterlands within the same geo-political unit eg Brazil. Thus the validity of the plantation model rests on the examination of the Caribbean case.

While the general case for a typology of systems demands reconsideration. there is much merit in looking at the Caribbean as a 'special case. The history is relatively short -500 years or less - and. with the exception of small communities of the original Amerindian inhabitants. the Caribbean peoples are the descendants of persons imported to service the specific interests of mercantile capitalism (ie plantation agriculture) and this mode of production continues to dominate most of the region's economies. including Cubas.

The PEM is divided into three phases. The first phase of pure plantation economy covers the period from the creation of large-scale slave plantations to emancipation ie from the mid seventeenth century to 1838. The second phase of plantation economy modified runs from emancipation to the great depression of the 19.30s. Following the inter-regnum of the second world war (which is given a significance that we shall encounter later) the current phase of plantation economy further modified sets in.

The central hypothesis of the model is

that the plantation legacy represents an endowment of mechanisms of economic adjustment which deprive 
the region of internal dy namic. More specifically, it involves patterns of income distribution and disposal which discriminate against economic transformation.

[Best and Levitt 1968:32]

Any proper assessment of the PEM must rest heavily on the analysis of the first phase which set the stage for the 'evolution' of the system. The usefulness of the model depends to a great extent on the rigour of the pure plantation economy analysis and the identification of the legacies inherited subsequently.

\section{Pure Plantation Economy}

Three main characteristics of the pure plantation economy are identified. First, the domestic economy of a plantation hinterland is structurally part of an 'overseas economy'; the other part being the metropole which is the locus of initiative and decision and

the critical linkage point between international demand and supply and the nexus through which the pattern of resource combination is determined.

[Best 1978:302]

The balance of payments account is the vital one and the only meaningful level of analysis is that of the overseas economy. Secondly, the pure plantation economy is characterised by the existence of "total economic institutions'-ie plantations - linked by no more than a law-and-order government. Each plantation obtains its supplies largely from abroad and exports its output. There is no response within the hinterland economy to changes in aggregate domestic demand. As a result.

the pure plantationeconomy is a segmented economy. The 'firm' is the meaningful unit of economic analysis.

[Best 1978:307]

The third characteristic is the 'incalculability' of value flows. This follows from the integrated nature of the plantation, with the utilisation of imputed accounting prices, including those of labour.

The hinterland economy is bound to certain 'rules of the game'set by the metropolitan power. These include the navigation provision which restricts all hinterland trade to approved shipping; the Muscovado bias, which limits the production process to terminal activity at the raw material stage; and the metropolitan exchange standard, which allows full convertibility with metropolitan currency at a fixed exchange rate and, with that, the assurąnce that the liabilities of financial operators in the hinterland are fully matched by assets in the metropole.

In its foundation period, the pure plantation economy experiences a golden age since its very initiation resulted from excess metropolitan demand and high prices. Here, certain patterns of behaviour are cemented. The first concerns expansion. Since supplies and capital goods are imported, the secondary effects of any expansion are felt in the metropole and the more accessible hinterlands of settlement. Domestic expenditure is restricted to a high income élite with a taste for imported goods. The second pattern is the form of adjustment to fluctuating earnings. While favourable conditions encourage expansion, unfavourable conditions cannot be met by contraction since slave labour is a fixed cost.

Adjustment therefore tends to take the form of political intervention by land policy to restrict entry into the business, and otherwise to support prices or reduce costs.

[Best 1978:289]

High prices and profits lead eventually to oversupply, falling prices and profits in the subsequent period. Moreover, mercantile profits now shift into the more lucrative industrial sector, developing rapidly, in the metropole itself, as industrial capitalism takes root.

The PEM suggests that the forms of adjustment are constrained by the characteristics and behavioural patterns of the plantation. In the mature plantation economy with all land engrossed by export production (for example Barbados and the Leeward Islands) there is widespread bankruptcy. New plantation economies benefit, since they offer virgin soils, allow the transfer of the most efficient technology, and can attract labour from the mature plantations (for example, Trinidad and Cuba in the nineteenth century). Mixed plantation economies offer the possibility of diversification but this is restrained by underconsumption of local output by the plantation élite and the low income of the ex-slave population (for example, Jamaica).

The economic crisis of the slave plantation economy coincides with the rise of industrial capitalism, with its hostility to market restrictions and to the subsidy to the planter élite. One result is emancipation of the slave population and, with this, the end of the phase of pure plantation economy.

\section{Post-Slavery Economy}

The major thesis of the PEM is that the Caribbean economy has undergone little structural change since emancipation in 1838. The model of pure plantation economy, accompanied by an accounting matrix, analyses the causal relationships between economic and social activity in the plantation hinterland and decision-making in the metropole. 
The question that arises is the validity of this analysis in the post-slavery period. Was the emancipation of the slaves and the later removal of imperial preference, with the declaration of free trade in Britain following the rise of industrial capitalism, marked by no structural shift in the nature of plantation economy? Best and Levitt concede that there was some diversification and deepening of the Maroon culture but insist that the legacy of pure plantation economy remains the decisive factor in comprehending the operation of Caribbean economies, with the exception of post1959 Cuba. Brown and Brewster suggest that the failure to specify properly the impact of the diversifying tendencies represents a serious limitation of the model:

concentration of the externally defined relationships of the plantation at the macro-economic level has obscured the need to examine in detail those very units that are not of the plantation; statements about the existence or non-existence of internal dynamic and the possibilities for its development represent merely articles of faith.

[Brown and Brewster 1974:52]

Perhaps in anticipation of such reservations, the model suggests that, while emancipation freed labour, the dominant plantation system and colonial government systematically cut off the areas of independent activity. In the mature plantation economies, with all or most land engrossed by plantation agriculture, freed labour had little choice but to cont inue working as subsistence wage labour. In the new plantation economies new forms of slavery were invented to import labour, largely from India, and lower the reserve price of labour. Simultaneously, the colonial authorities effectively legislated against land ownership by most of the ex-slave population. The mixed plantation economies were able to achieve the highest levels of diversification as existing trends allowed greater 'room for manoeuvre'.

The emancipation of the slave population, in all types of plantation economies, allowed a strengthening of the natural tendency towards independent social and economic activity, long evident in the isolated Maroon communities of runaway slaves, and in the own-account production of food crops by the slave population on any small plots of land available. Emancipation led to the blossoming of food crop production and of an infrastructure of footpaths and roads to facilitate distribution to expanding market centres. There was also a diversification of export crop production with the introduction, by the ex-slaves, of crops such as bananas. Some of the freed population moved to the towns and formed an artisan class highly skilled in house and furniture building, clothing and footwear manufacture and tool-making. This independent activity was nurtured by cooperative ventures within families and communities.

The plantation model identifies such rural and urban activities as components of the residentiary sector-the only evidence of structural transformation and of the lessening of the legacy of the slave economy. However, it is posited that such dynamic, internally propelled tendencies for independent economic enterprise, and consequently structural transformation, were restrained by a number of inherited inbuilt characteristics. The first, and perhaps most important, was a hostility to such independent activity from the dominant planter interests and their planter government, supported by the military muscle of the colonial power. We have already noted the mechanisms used to ensure the availability of cheap labour, alienated from the means of production, in mature, mixed and new plantation economies. The plantation experience produced a free labour force with a limited range of skills, and fewer opportunities for learning others, given the specialised nature of export agriculture. It also left a legacy of taste for imported wares which led free labour either to work part-time on the plantations or to devote some of their own acreage to production of export crops, in order to generate the cash income to service this taste pattern. Thus, whatever the wage rate or price of export crops, free labour would devote a share of its labour time to production of export crops. The low levels of income and the inherited import-oriented taste patterns reduced effective demand for locally produced goods and services and, thus, the dynamic potential of the residentiary sector.

In the formal model of Best and Levitt, the development of the residentiary sector coincides with the second phase, plantation economy modified, which began after emancipation and continued until the breakdown of the world economy during the 1930s, culminating in the second world war. This inter-regnum is heavily emphasised by the plantation economy theorists. In this war period, with a high level of closure, the Caribbean economies (like those of most other similarly affected Third World economies) experienced a substantial shift to production for local consumption. Food crop production doubled in Trinidad and Tobago while artisan craftsmen began to supply displaced demand for unavailable imports [TTRIWI 1979, Beckford 1974). The great depression led to a massive fall in demand for all goods in metropolitan markets including those from the plantation economies. The result was large-scale unemployment, social dislocation and an eruption of political rebellion, beginning in St Kitts in 1934 and running throughout the archipelago of English-speaking Caribbean islands. The British Government responded with repression of the leadership 
and the dispatch of Commissions of Enquiry [see Lewis 1950 ).

The colonial government proposed an increase in grants-in-aid for welfare purposes and the stimulation of some industrial activity. This coincided with the growth of postwar anti-colonial movements which demanded political independence and economic development. These efforts were to culminate in political independence and the introduction of schemes of import substituting industrialisation. This last period is represented in the model by a new sector-the new dynamic sector. reflecting the import substituting effort.

Thus the plantation economy of today is said to consist of these three sectors: traditional export sector. residentiary sector and new dynamic sector. the first and last being highly integrated into the world economy but very little with the residentiary sector or with each other. Newly created economic activity can be placed in any sector depending on its characteristics. For example. the model places petroleum and bauxite mining and tourism within the traditional export sector. the justification being that these new activities exhibit a form of incorporation into the plantation economy similar to that of the archety pal sugar plantation. That is. they are total institutions. with global vertical integration and few structural linkages with locally producing sectors.

\section{Accounting Framework}

The accounting framework appended to the model attempts to disaggregate each sector in a modified input-output matrix into its functional parts and hypothesises that there are few inter-industry linkages. The matrix suggests that there is no consolidated capital market. since

in plantation economy. there does not exist an aggregate 'pool' of savings available to finance investments of all types.

[Best and Levitt 1968. vol 3:13]

Each sector. and firms within each sector. particularly foreign owned firms. retain savings generated for their own investment purposes.

If the accounting framework of the PEM were to be adopted by Caribbean statistical offices (as has been attempted to some extęnt in Trinidad and Tobago) there would be. no doubt. an enriched data base for theoretical refinement. There is much fragmentary evidence /eg Francis 1962. Best and Levitt 1968| and an intuitive sense. informed by the historical evidence. to suggest that the model will be 'proved' correct and remain largely intact if the data could be collated to fit the categories of its accounting framework. The model can be expected. therefore. to have descriptive power.

However, if it is to be a useful tool for future planning. it must possess predictive power. ex ante, and be capable of isolating the key causal variables which need to be manipulated to shift the entire system. Although it may be possible to develop the model to allow these criteria to be satisfied, these cannot be met by the present state of elaboration. It is perhaps this limitation which allows Blackman to argue that the plantation economy model is a theory of underdevelopment and cannot form an operational model to assist in formulating a stategy for economic development | Blackman 1979:33|. Brown and Brewster hint at a similar conclusion when they state that to the extent that the accounting matrices represent Caribbean history and economic reality more accurately their dynamic potential is diminished [ Brown and Brewster 1974:51]. Both Blackman and the others appear to recognise the absence of a predictive dimension to the model. However, if this cannot be elaborated then the model is of limited economic usefulness from a planning perspective. The model's accounting framework could still be an interesting tool for periodic review of the impact of economic policy on the structural transformation which is the main objective. Todevelop economic policy. however. demands a differing level of abstraction in order to identify the critical variables to be manipulated.

The plantation model seems unclear about the distinction noted above. Thus. one volume claims that the accounting framework for plantation economy further modified is not applicable to postrevolutionary Cuba | Best and Levitt 1968. vol 3:2|. the implication being that the failure to implement an import-substituting industrialisation for a higher income élite represents a significant departure from the rest of the Caribbean. Which it does. However. after an initial attempt at heavy industry. Cuba has reverted to concentration on export agriculture. particularly sugar. with some diversification within the sector eg production of single-cell protein or of animal feed from molasses.

The persistence of traditional export production under a populist regime committed to the betterment of the mass of the population. as opposed to the oligarchic regimes in most of the remaining Caribbean. raises serious questions about the type of structural transformation possible in 'small' economies. (In the Caribbean context Cuba is a large economy.)

McIntyre has long indicated the distinction between functional contraints to development resulting from the form of incorporation into the world economy and 
the structural constraints resulting from size and resource endowment [ McIntyre 1971]. Demas important work on small economies tended to concentrate on the structural constraint. while Best s work stresses functional bottlenecks. This comes out clearly in his review of Demas book [Demas 1965, Best 1971]. The persistence of the structural constraint in Cuba does suggest the need for a reassessment of the emphasis of the Best and Levitt model on structural transformation. as both the necessary and sufficient condition for Caribbean transformation.

A more recent application of the model to Trinidad and Tobago by Best and others. sugests that:

the economics of deliberate change needs to focus on those institutions and mechanisms which inhibit and sometimes stunt the natural process by which a society would normally feed, clothe and shelter its people out of the resources of its own place and through the resourcefulness of its own people.

|TTRIWI 1979:1. emphasis added|

This notion of a natural process' which 'normally' applies appears surprisingly ahistorical given the Caribbean historical experience and the historical methodology proposed by the PEM. and/or to be overly influenced by the history of Western Europe and a stages-of-growth model. The implicit assumption seems to be that one can return to a precolonial period.

This view. which can only be described as romantic. fails to understand the larger fact of life that one cannot go back. It finds echoes in the proposals for closure which occur in other Caribbean work such as that of Thomas [1974|. To be fair. both Best and Thomas proposed partial closure. with the retention of an export sector but with differing forms of integration both with the international and national market, and assumed increased levels of regional economic integration. The major assumption, however. at least in the work of Best. is that structural transformation is possible. necessary and sufficient for socio-economic development. Thus the redistribution of income and the satisfaction of basic needs clearly evident in Cuba today may be undervalued within the formal model, if the emphasis is on structural integration which the accounting framework may show to be persistently limited in Cuba today. Perhaps it is this aspect of the model which leads Sudama |1979| to term it 'economistic'.

The limitation of the PEM is that its preoccupation with structural change diverts attention from the structural constraints of size and resource endowment. More important. the formal model does not note that the process of consolidation of plantation and other foreign interests required the collaboration of indigenous groups. In the case of the slave-based pure plantation economy one could specify two distinct classes-planters and slaves - whose interests were diametrically opposed to each other and who were linked to the production process in a mutually antagonistic relationship. The question is how did this antagonism evolve in the postemancipation period and particularly since political independence?

Best appears ambivalent on this question. At one point he makes the absurd claim that

$$
\text { we are all working, therefore we are working class. }
$$

|Oxaal 1975]

Elsewhere. and perhaps more reflectively, he suggests the existence of an oligarchy comprised of local businessmen. leaders of the ruling party. trade union leaders and professionals. who provide local support for continued metropolitan domination of the economy. However. the basis of this oligarchy's support for foreign economic interests is perceived to lie in 'gratification' of a material and psychic nature. The reason for the inability of this oligarchy to break from metropolitan domination is seen to result from the -Afro-Saxon culture which is defined not as a term of abuse but one to fit

the framework in which the West Indian psyche was formed, a particular cultural contact between the fragment of rulers who came from the Atlantic maritime nations... and the people they brought in, essentially African peoples. [ [Best 1968:13]

While an oligarchy is acknowledged to exist. the specific European categories of 'bourgeois' and proletariate' are rejected.

Moreover, while it is assumed that this oligarchy obtains a gratification-material and psychic - from support of foreign economic control, Best argues that the population cannot be mobilised on the basis of any such division since the factor in mobilisation is consciousness and no one knows how the latter is formed. The political strategy. therefore has to be one of 'playing for change'.

No doubt there is justification in suggesting the psychological nature of suport for foreign economic domination. The dehumanisation of slavery and indenture. and the foisting of European cultural values on Caribbean peoples has produced a schizoid personality. brilliantly analysed by Fanon | 1968|. It produces an ambivalent personality much evident in the fire-eating populist leaders of the anti-colonial struggles. unable even to shed their jackets and ties. There is earlier evidence in the royal courts created 
by the leaders of the Haitian Revolution. Nevertheless it is possible to distinguish in practice between the disadvantaged groups and those who obtain material gratification (and psychic satisfaction) in abundance. Although it is incorrect to reach any simplistic conclusion on the nature of divisions in the society in order to devise a strategy for mobilisation, Best's ambivalence on this point may have been responsible, if only in part, for the limited success of his political involvement to date.

To a large extent, the political and social analysis is not central to the validity of the formal model. On the other hand, the limitations of the social and political analysis do raise issues about the method of the formal model itself. It is difficult to locate the methodological basis of the PEM since there is little explicit discussion of method. Best himself may claim that the very attempt to categorise the method is irrelevant and an indicator of the 'intellectual imperialism' which forces Third World scholarship to seek acceptance in metropolitan terms. It is stated that the approach draws heavily on Caribbean historical analysis to

stress the methodological point that economists have to rely on historians to discover, check and make available the source materials which are their input, as it were.

[Best 1978:289, footnote 15]

But there is no such thing as an 'historical approach'. Each historian brings to the particular area of study a particular way of looking (philosophy) which determines what is perceived. By and large, the historical sources cited by the model utilise marxian or neo-marxian materialist analysis. However, the persistent danger of the historical approach is that it can allow a clever reorganisation of the original historical material, with no added insight of substance.

\section{Conclusions}

The PEM is a substantial contribution to the analysis of the Caribbean economy. Its major limitation is its failure to provide the causal and predictive analysis demanded for economic planning. However, further development of the work by Best, Levitt or others, may yield these requirements. The failure, also, to specify the socio-political divisions created nationally by the plantation economy leads to an overemphasis on structural transformation. This is influenced by a romantic, stages-of-growth assumption which allows the conclusion that there is some 'natural process' of provisioning which 'normally' applies. Such an assumption is overly deterministic and economistic. The very fact of plantation economy introduced a size of population in relation to resource base which may not allow any matching of resource use and supply.
Moreover, inherited taste patterns cannot be completely reversed. Even if they could, there would be serious problems. For example, 90 per cent of the protein requirements of the Trinidad and Tobago population is met from imports. While local food production may replace supply in quantity, it will be more difficult to provide the protein supply, or the mix of nutrients available from imported food. This is not an argument for an open economy but simply a caution on the implications of any crude closure. The emphasis on structural transformation is important, but the issues of size (including population) and resource endowment demand serious attention.

In the absence of a benefactor, socialist or otherwise, as in the case of Cuba, the price of closure may be a kind of 'barracks equality' and the glorification of a 'cult of poverty', not as a stage during which the productive forces are being developed but as the outer limit of possibility without the inequalities that may result from opening the economy. While that may or may not be undesirable, it needs to be anticipated, particularly by those who advocate closure as the political solution 'from below'. The Cuban experience also illustrates that one can increase the general standard of living and societal cohesion as a result not of dramatic structural transformation but of the control of the foreign economic interests which divide the society for their own benefit.

The economic experience of the Caribbean countries since the mid-1970s indicates the need for a searching analysis of the PEM. Since 1975, all the Englishspeaking Caribbean countries, with the exception of Trinidad and Tobago with a petroleum resource, have suffered from severe balance of payments deficits. Without exception, they have all suffered from high inflation rates, growing unemployment, social protest and high crime rates. In a recent newspaper report, $\mathrm{C}$. Blackman, the Governor of the Central Bank of Barbados, places the major share of the blame for the region's economic problems on the social science faculty of the University of the West Indies. While that is a patent absurdity, especially as faculty members and regional governments have long been at political loggerheads, there is some truth in the charge that there is relatively little critical comment on the PEM (or on what appears to be a new 'bible'-the work of Thomas [1974|). In a controversial review of Girvan's article [Girvan 1973], George Cumper warns of the use of ideology as a device for creating closed political circles /Cumper 1974|. Cumper's fears appear somewhat exaggerated but there is a possibility that the absence of critical analysis of the PEM (or of Thomas' work) can lead to the intellectual hero-worship that has foisted all types of incompetents on Caribbean society [see also Lewis 1974]. 
In this article we have tried to steer a course between uncritical acceptance and uncritical dismissal of the relevance of the model, extremes to which discussion of the wider dependency school has also tended to polarise. in doing so we hope to have made some contribution to the resolution of the larger theme of this issues of the Bulletin.

note: the more general dependency references are not given here but in the bibliography at the end of this Bulletin.

\section{References}

Beckford, G., 1972, Persistent Poverty, Oxford University Press

- 1974, 'Towards independent economic development for the betterment of Caribbean peoples', The Massachusetts Review, vol 15

Best, L., 1965, 'Chaguaramas to slavery', New World Quarterly

- 1968, 'A model of pure plantation economy', Social and Economic Studies, vol 17 no 3, September

-1971 , 'Size and survival' in N. Girvan and O. Jefferson (eds), Readings in the Political Economy of the Caribbean. New World, Trinidad

$-1971 \mathrm{a}$, 'Independent thought and Caribbean freedom' in $\mathrm{N}$. Girvan and $O$. Jefferson (eds), ibid

- 1978, 'Externally propelled economy', Proceedings and Papers from the Caribbean-American Exchange Programme, The Phelp Stokes Fund

- with K. Levitt, 1968, Extemally propelled industrialisation and growth in the Caribbean, vols 1-4, McGill Centre for Developing Area Studies, Montreal, mimeo

- with K. Levitt, 1975, Pure Plantation Economy, Institute of International Relations, University of West Indies

Blackman, C., 1979. The Balance of Payments Crisis in the Caribbean: Which Way Out?, pamphlet, Barbados Central Bank, February
Brown, A. and H. Brewster, 1974, 'A review of the study of economics in the English-speaking Caribbean', Social and Economic Studies, vol 23 no 1, March

Cumper, G., 1974, 'Dependence, development and the sociology of economic thought', Social and Economic Studies, vol 23 no 3 , September

Demas, W., 1965, The Economics of Development in Small Countries with special reference to the Caribbean, McGill Press, Montreal

Fanon, F., 1968, Black Skins, White Masks, McGibbon and Kee, London

Francis, A. A., 1962, A Note on Inter-Industry Relations in the Economy of Trinidad and Tobago, Research Papers, Trinidad and Tobago Central Statistical Office, no 2

Girvan, N., 1973, 'The development of dependency economics in the Caribbean and Latin America: review and comparison', Social and Economic Studies, vol 22 no 1, March

- 1971, Foreign Capital and Economic Underdevelopment in Jamaica, Institute of Social and Eoonomic Research, University of the West Indies

Jefferson, O., 1972, The Post-War Economic Development of Jamaica, Institute of Social and Eoonomic Research. University of the West Indies

Lewis, W. A., 1950, 'The industrialisation of the British West Indies', Caribbean Economic Review, vol 12, May

Lewis, G., 1974, Caribbean Ideologies, Tapia, March 31

McIntyre, A., 1971, 'West Indian trade issues' in Girvan and Jefferson (eds), op cit

Oxaal, 1., 1975, 'The dependence economist as grassroots politician', in Oxaal et al (eds), op cit

Sudama, T., 1979, 'The model of the plantation economy: the case of Trinidad and Tobago', Latin American Perspectives, vol 1 no 2 , Winter

Trinidad and Tobago Research Institute of the West Indies (TTRIWI), 1979, International Cooperation in the Industrialisa tion Process: the Case of Trinidad and Tobago, report prepared by the TTRIWI for the Joint UNIDO Study on International Industrial Cooperation, January 